\title{
Die toekoms van universitêre navorsing in Suid-Afrika
}

Daar word algemeen aanvaar dat die Suid-Afrikaanse universiteit 'n drievoudige rol het, nl. kennisoordrag (onderrig), die inwin van nuwe kennis (navorsing) en sinvolle gemeenskapsdiens voortspruitend uit sy onderrig en navorsingsopdrag. Die prominente rol wat kennisontdekking (navorsing) aan universiteite speel, onderskei hierdie inrigtings egter van alle ander nasekondêre onderwysinstellings wat oorwegend met kennisoordrag te doen het. Ten einde waarlik universiteit te bly, is dit dus essensieel dat hierdie inrigtings sal strewe om die unieke akademiese kultuur noodsaaklik vir navorsingsbevordering jaloers te vertroetel. In die huidige tydsgewrig is dit duidelik dat universitêre navorsing sekere bedreigings moet voorsien. In landsbelang vertrou 'n mens dat hierdie probleme uitgeken en aangespreek sal word.

1. Onvoldoende finansies: Universitêre navorsing het waarskynlik nog altyd gebuk gegaan onder finansieringsprobleme. Om die omvang hiervan wetenskaplik te bepaal, sou egter haas onmoontlik wees - en onteenseglik wissel dit aanmerklik van inrigting tot inrigting. Benewens jaarlikse insette van die Wetenskaplike Adviesraad het ons ook geen doeltreffende nasionale wetenskapsbeleid wat navorsingsfinansiering sinvol koördineer nie. 'Statistiek ${ }^{2}$ toon wel dat Suid-Afrika se Navorsings- en Ontwikkelingsbesteding ( $\mathrm{N}$ en $\mathrm{O}$ ) ver onder dié van nywerheidslande is. Wanneer $\mathrm{N}$ en O-besteding egter met dié van ontwikkelende lande met vergelykbare ekonomieë vergelyk word, vertoon ons beter: De Villiers ${ }^{2}$ bereken dat Suid-Afrika in 1989/1990 0,9\% van sy Bruto Binnelandse Produkte (BBP) aan N en O bestee het ongeveer soveel as Indië en Ierland, effe meer as Brasilië en Meksiko, maar heelwat meer as Nigerië,
Turkye en Egipte. Die ontstellende statistiek is egter dat $\mathrm{N}$ en $\mathrm{O}$-besteding oor die afgelope dekade afgeplat en selfs gedaal het. Binne die tersiêre sektor het $\mathrm{N}$ en O-besteding tot 1986 gestyg waarna 'n daling ingetree het, meer prominent vir die geesteswetenskappe as die natuurwetenskappe. Ook betekenisvol was 'n onlangse verslag voor die Wetenskaplike Adviesraad $^{3}$ dat slegs $8 \%$ van direk staatsgefinansierde navorsing aan universiteite gedoen word. $44 \%$ geskied binne wetenskapsrade se eie navorsingseenhede (met die leeueaandeel binne die WNNR). Die oorblywende $48 \%$ word gespandeer op algemene universiteitsubsidies vir akademiese salarisse wat dan indirek ook navorsing ondersteun.

Huidige staatsbeleid waarvolgens navorsingsrade progressief besnoei word met die beleidsveronderstelling dat meer eie geld deur profytmakende navorsingsaktiwiteite genereer moet word, is waarskynlik alleen vir die WNNR haalbaar. Dit beteken in die praktyk nie slegs dat minder fondse na universiteite gaan nie, maar ook dat die ewewig ten gunste van kommersieel lewensvatbare toegepaste en ontwikkelingsprojekte en tot nadeel van basiese navorsing skeefgetrek sal word. 'n Saak kan voorts uitgemaak word dat omskepping van die WNNR tot 'n sentrum vir toegepaste en ontwikkelingsnavorsing effektief die einde beteken van 'n nasionale sentrum waar uitstekende basiese navorsing voorheen dikwels, in samewerking met universiteite, gedoen is. ${ }^{4}$ Teoreties, en mits staatsfondse ooreenkomstig verskuif word, sou dit natuurlik daartoe kon lei dat basiese navorsing (tevore aan die WNNR gedoen) nou na universiteite verplaas word. Tot dusver is daar egter 
min bewys dat so jets wel gebeur.

'n Ondersoek van die SNO het aan die lig gebring dat gesofistikeerde navorsingstoerusting aan universiteite kommerwekkend verouder omdat fondse vir verplasingsprogramme ontbreek. ${ }^{5}$

Kontraknavorsing bied geleentheid vir navorsingsfinansiering losstaande van staatsubsidies, en speel ook 'n groeiende rol aan universiteite. Nie alle dissiplines kan egter beduidend hierby baat nie. Daar moet ook gewaak word teen ongewenste navorsingsbeinvloeding deur betrokke finansieringsinstansies, maar in die praktyk bring dit selde beduidende probleme mee. Privaatsektorfinansiering is veel meer geredelik vir tegnologiese en natuurwetenskaplike navorsing, as vir geesteswetenskaplike navorsing beskikbaar.

In reaksie op persepsies dat wetenskapsontwikkeling nie hoog aangeslaan word nie, het die Staatspresident onlangs nog verseker dat sy regering $\mathrm{N}$ en O-finansiering vorentoe prioriteitsaandag sal gee. ${ }^{\circ}$ Die Departement Nasionale Opvoeding se Onderwysvernuwingstrategie-dokumente (1992) spreek navorsingsfinansiering nie direk aan nie. ${ }^{7}$ Uit geledere van die sg. Breë Demokratiese Beweging (BDB) wat in 'n nuwe staatkundige bedeling sekerlik beduidende inspraak sal hê, is daar tans nog verwarrende seine oor wat universiteite t.o.v. staatsfinansiering kan verwag. Uitbreiding van die nasekondêre onderwyssektor word oënskynlik gesteun, maar technikons word hoër aangeslaan as universiteite. ${ }^{8}$ Terwyl Samuel $^{9}$ onlangs verklaar het dat die ANC navorsingsfinansiering aan universiteite hoog aanslaan, het ander woordvoerders sowel as die National Education Policy Investigation (NEPI-verslag, 1992) ${ }^{8}$ inkorting van universiteitsubsidies (en dus onvermydelik ook navorsingsfinansiering) voorgestaan ten einde primêre en sekondêre onderwys prioriteit te gee. Dit is ook aanbeveel dat tradisioneel swart universiteite subsidiegewys bevoordeel moet word ten koste van tradisioneel blanke (vermoedelik ryker) universiteite.

2. Toepaslike navorsing: Die groeiende aandrang op toepaslike navorsing ${ }^{9}$ is in wese gesond, solank die begrip, toepaslikheid, nie beperk word tot dit wat korttermyn-, onmiddellik meetbare impak in die handel, bedryfs- of wetenskapswêreld het rie. In 'n ontwikkelende land soos Suid-Afrika is dit nodig om toegepaste en ontwikkelingsnavorsing te beklemtoon, die resultate waarvan snelle en bepaalbare rendemente ten opsigte van menslike hulpbronontwikkeling, tegnologiese vooruitgang en rykdomskepping kan bring. Hoe belangrik hierdie aspek ookal is, moet egter onthou word dat tegnologiese deurbrake feitlik sonder uitsondering uit fundamentele navorsing gespruit het, die motivering waarvoor gewoonlik intellektuele nuuskierigheid en nie finansiële gewin was nie. ${ }^{1.11}$ Verwaarlosing van langtermyn-, selfs onvoorsienbare, voordeel uit navorsing moet eventueel tot ernstige nadeel van die gemeenskap inwerk.
En die bakermat van basiese navorsing was nog altyd akademiese instellings soos universiteite.

Dit is voorts insiggewend om daarop te let hoedal markgedrewe (toepaslike) navorsing in industriële lande soos Brittanje en die VSA alan't verander is. In die vroee Thatcher-era bv. is navorsers al hoe meer gedwing om finansiële steun te vind in korttermyn- en kontraknavorsing, mel duidelik demonstreerbare voordele vir die nywerheid en mark. Mettertyd het die pendulum teruggeswaai totdat mev. Thatcher self opgemerk het: "The greatest economic benefits of scientific research have always resulted from advances in fundamental knowledge rather than the search for specific applications." Ook tydens die Reaganadministrasie het die aanvanklike beleid van voorkeurfinansiering vir navorsing met duidelike impak op nasionale prioriteitsprogramme, mettertyd verander totdat die President self verklaar het dat basiese navorsing die hoeksteen van Amerikaanse mededingendheid is. ${ }^{4}$

Daar kan verwag word dat 'n nuwe bedeling by sowel universiteitsonderrig as navorsing mag aandring op groter "Afrikanisering" - d.w.s. die pertinente aanspreek van probleme van ons streek en kontinent." Hiermee saam waarskynlik ook aandrang op regstellende aksie ten einde ras- en geslagsratio's by navorsingspersoneel in ons blank en manlik gedomineerde universitêre navorsing aan te spreek. Hierdie dinge is nodig, mits die klem onverbiddelik bly val op kwaliteit akademiese strewe en navorsing.

3. Afrika-realiteite: Alhoewel nasekondêre onderwys in Afrika, volgens 'n onlangse Wêreldbank-verslag, ${ }^{10}$ oor die afgelope drie dekades gekenmerk is deur snelle uitbreiding van onderwysinrigtings en studentegetalle, was daar terselfdertyd 'n katastrofiese verlaging in akademiese standaarde. Navorsing in besonder is ' $n$ ernstige knou toegedien. Hierdie situasie word toegeskryf aan 'n kombinasie van faktore, soos ekonomiese insinkings, swak en korrupte bestuur, emigrasie van kundige akademici, en staatsinmenging, met ernstige benadeling van akademiese vryheid en outonomie. Uit hierdie verslag kan ons veel leer om foute wat elders op ons kontinent begaan is, te vermy en ook ag te slaan op die waarskuwing dat, alhoewel primêre en sekondêre onderwys inderdaad van kardinale belang is, tersiêre onderwys (en dus ook navorsing) nie afgeskeep mag word nie.

Ten spyte van vermelde bedreigings sou universitêre navorsing in Suid-Afrika kwaliteitsbydraes kon bly lewer mits sekere vereistes nagekom word:

Dit lyk wenslik (soos ook in die NEPI-dokument uitgespel) ${ }^{8}$ dat Suid-Afrika op die pad vorentoe 'n meer gediversifiseerde, selfs gestratifiseerde tersiêre onderwysbedeling sal ontwikkel, wat o.d. daartoe kan lei dat nie alle universiteite sal poog om uitstaande navorsingsinrigtings te wees nie. Interuniversitêre samewerking om sentra van uitmuntendheid op te bou, lyk essensieel. Ten einde in wese universiteit te 
bly, sal alle universiteite egter wel 'n hoeveelheid navorsing wil doen. Of navorsing aan individuele inrigtings dan oorwegend toegepas eerder as basies is, maak nie soveel saak nie, mits dit kwaliteit werk is wat onder andere steeds erkenning vanuit die internasionale wetenskapsgemeenskap sal geniet. ${ }^{11}$ Enige toegewing t.o.v. kwaliteit sal ons onvermydelik op 'n glybaan na middelmatigheid en eventuele irrelevansie plaas. Natuurlik is dit belangrik dat unieke omgewingsaard 'n faktor sal wees wanneer oor toepaslikheid en standaarde besluit word. Die standpunt word al meer gehoor dat ons in Suid-Afrika onafhanklik moet dink en nie gebonde moet voel om in akademiese sake geykte Westerse internasionale standaarde as norm te neem nie $^{8}$ - die sg. argument rondom Eurosentrisme en Afrosentrisme. In die finale instansie bly dit egter onvermydelik so dat die ingeligte internasionale wetenskapsgemeenskap 'n beslissende oordeel sal bly fel oor die meriete van ons navorsing.

Gegewe die waarskynlikheid dat staatsbefondsing vir universitêre navorsing in die afsienbare toekoms nie sal vermeerder nie (inderdaad mag verswak), het dit nou dringend noodsaaklik geword dat ' $n$ sinvolle nasionale navorsings- en tegnologiebeleid geformuleer word, om prioriteite te bepaal en navorsingsteun op 'n vaste voet te plaas. 'n Verslag van die International Development Research Centre (Kanada) deur die BDB aangevra ${ }^{12}$, bevat reeds interessante voorstelle in dié verband. Die daarstelling van 'n minister vir wetenskap en tegnologie (soos reeds in Japan en Duitsland bestaan) kan oorweeg word ${ }^{11}$ - 'n apolitiese deskundige wat in belang van ons land navorsing sal stuur en stimuleer, maar terselfdertyd die versoeking weerstaan om onredelik voorskriftelik te wees.

Die Komitee vir Universiteitshoofde het so pas 'n staande Navorsingskomitee in die lewe geroep - 'n deskundige liggaam wat veel sou kon doen om universitêre navorsing te bevorder. 'n Sterk saak kan byvoorbeeld uitgemaak word dat navorsingsrade meer fondse na universiteite moet kanaliseer eerder as om in eie navorsing te belê. ${ }^{3}$ Basiese navorsing in besonder behoort sover moontlik 'n universitêre tuiste te vind, en oorwegend deur staatsfondse gefinansier te word. Hoewel dit onsinnig is om duur navorsing wat elders in die wêreld doeltreffend gedoen word, te dupliseer, is 'n mate van oorvleueling nie noodwendig onverstandig nie - daar moet ruimte geskep word vir die seldsame, skeppende genieë aan wie universiteite by uitstek tuistes kan bied. Dit word natuurlik aanvaar dat technikons in groeiende mate by veral ontwikkelingsnavorsing betrokke sal raak.

Tegnologiese en natuurwetenskaplike navorsing word met reg beklemtoon, is in 'n groeifase en sal vorentoe sekerlik sterk ontwikkel. Die oënskynlike kwyning van, geesteswetenskaplike navorsing stem egter tot kommer. ${ }^{2}$ Dit is ongelukkig 'n gegewene dat die humaniora t.o.v. navorsingskultuur by die natuurwetenskappe agterstaan. Gesien die feit dat die oorwig van Suid-Afrika se huidige en korttermyn- voorsienbare probleme sosio-ekonomies en geesteswetenskaplik van aard is, is dit juis nou belangrik dat navorsing op hierdie terrein aangemoedig en uitgebou word. Aandrang op gemeenskapsgerigte navorsing, veral ter opheffing van veragterde gemeenskappe, word tereg al sterker en bied mooi ontwikkelingsmoontlikhede vir geesteswetenskaplike navorsing aan universiteite.

Daar word soms beweer dat navorsing (en basiese navorsing in besonder) vir die Derde Wêreld 'n luukse is wat waarskynlik nie bekostigbaar is nie. Lutjeharms' maak 'n oortuigende saak uit dat navorsing juis 'n essensiële deel van die kultuurmondering van die ontwikkelende wêreld moet wees en bly. In sy oorgangstydperk is dit vir Suid-Afrika dan essensieel dat veral universiteite hulle sal toelê op die skep en uitbou van 'n navorsingskultuur sodat ook (en veral) studente uit ontwikkelende gemeenskappe die waarde hiervan kan ervaar. Die skepping van so 'n milieu kom nie vanself nie en kom nie oornag nie - dit verg van 'n inrigting langtermyntoewyding, interdepartementele samewerking en die daarstelling van selektiewe navorsingshulp- en ondersteuningsaksies. 'n Basiese filosofie behoort die ondersoekkultuur te rig - die fundamentele tog eenvoudige norm wat Karl Popper gedefinieer het as die vind van bevredigende verklarings vir alle sake wat oënskynlik verklarings nodig het. Tog moet goeie navorsing altyd op realisme en perspektief gebou word ten einde te voorkom waarteen Sidney Harris waarsku: "If we lack concept, we run the risk of monumentally achieving what was not worth doing in the first place." 13

\section{LITERATUURVERWYSINGS}

1. Lutjeharms, J.R.E. (1992). Navorsingsbeleid sonder navorsingskultuur. Referaat: Jaarvergadering, S.A. Akademie vir Wetenskap en Kuns.

2. De Villiers, L.S. (1992). Tien jaar van navorsing (Sentrum vir Wetenskapsontwikkeling, Pretoria)

3. Lion's share goes to C.S.I.R. (1993). Science Policy Digest, 6(3).

4. Lutjeharms, J.R.E. \& Thomson J.A. 1993. Commercializing the C.S.I.R. and the death of science, S.A. Journal of Science, 89, 8.

5. Pouris, A. 1993. Research infrastructure in a crisis, Science Policy Digest, 6(1).

6. The State President on the rôle of Science and Technology in the future South Africa (1992). Science Policy Digest, 5(1).

7. Onderwysvernuwingstrategie (1992). (Departement van Nasionale Opvoeding, Pretoria).

8. National Education Policy Investigation: Post-secondary Education (1992). Project of the National Education Co-ordinating Committee. (Oxford Press/NECC, Cape Town).

9. McGregor, K. (1993). Wind of Change, The Times Higher, 1056,.

10. Saint, W.S. (1992). Universities in Africa, World Bank Technical Paper, 194.

11. Sellschop, F. (1992). The rôle of research in society: Quest for excellence in research, Supplement to Wits Reporter.

12. Towards a science and technology policy for a democratic South Africa (1992). Report by the International Development Centre (Canada).

13. Austin, J.C. 1987. On the philosophy of research, $M R C$ News, $18(3), 16$ 